\title{
Performance of Japanese larch and the Dunkeld hybrid larch at the Petawawa Forest Experiment Station
}

\author{
M. J. HOLST
}

Canadian Forestry Service

Petawawa Forest Experiment Station

Chalk River, Ontario

This note reports on the superior growth of 43-year-old Japanese $x$ European larch (Larix eurolepis Henry) compared with Japanese larch (L. leptolepis (Sieb. and Zucc.) Gord.) in a continental climate at Petawawa Forest Experiment Station, Chalk River, Ontario.

The seed was collected on Japanese larch near Dunkeld House in Perthshire, Scotland, and contained many hybrids with European larch (L. decidua Mill.), the latter growing within pollination distance. It was from seed collected from the same trees that Professor A. Henry described the first Japanese $x$ European larch hybrids which he called the Dunkeld hybrid larch - L. eurolepis Henry (Henry and Flood 1919).

The plantation at Petawawa Forest Experiment Station is the oldest planting of the Dunkeld hybrid larch in North America where it grows in a continental climate. It is of interest, therefore, to record the trees' performance.

In 1928 about 400 seedlings were planted on fertile, well drained sandy loam with the water table at about $3-4 \mathrm{ft}(0.9-1.2 \mathrm{~m})$. By the fall of 1938 the trees averaged $15 \mathrm{ft}(3.2 \mathrm{~m})$ in height. Recurrent porcupine damage was severe and in 1941 the plantation was thinned to remove more heavily damaged trees; a fence was also erected around the eastern part of the plantation to exclude porcupines. In 1950 the lower trunks of the 20 remaining trees were protected by metal sleeves to prevent the porcupines from climbing the trees.

The botanical identity of the remaining 20 trees was checked in the fall of 1966 when the plantation was remeasured. Eixteen were hybrids and four were pure Japanese larch. Five hybrid trees were so badly damaged by porcupine that they were rejected for the growth comparison (Table 1). At 43 years the mean height of the Dunkeld hybrid was $65.2 \mathrm{ft}(19.87 \mathrm{~m})$ while that of the Japanese larch was only $49.2 \mathrm{ft}(15.00 \mathrm{~m})$; respective diameters were 14.6 inches $(37 \mathrm{~cm})$ and 12.5 inches $(32 \mathrm{~cm})$. The differences were significant. Thus the
Dunkeld hybrid larch was superior to the Japanese larch in height, diameter and volume by 33,15 and $73 \%$ respectively. This is probably an expression of hybrid vigour, but the test lacks the European larch control to prove this point.

Since 1935 Dave Cook of Albany, New York, has worked intensively with the Dunkeld larch in eastern Rensselaer County, New York where there are optimal growing conditions for Japanese larch. $\mathrm{He}$ already has the fourth generation of selected progenies (Cook 1969). His experience is that "the Dunkeld larch tends to combine the best characteristics of each parent - straightness of stem and sometimes light branching from the European, vigorous growth, early and abundant flowering and relative freedom from pests of the Japanese" and he finds "no evidence of any strong general tendency for the hybrids to deteriorate with succeeding generations beyond the original interspecific cross". A comparison in Saratoga County, New York, of 25-year-old larch indicated that the volume production of the Dunkeld hybrid was superior to both the Japanese larch and the Scottish race of the European larch respectively by $4 \%$ and $32 \%$. The Dunkeld hybrid had much better stem and branch form than Japanese larch (Eliason and Carlson 1963). However, the hybrid tested was probably an $F_{3}$ which normally would be less vigorous than an $F_{1}$.

The Dunkeld larch has been a success in areas in New York with more than 40 inches $(1010 \mathrm{~mm})$ of precipitation per year. In the more continental and drier climate at the Petawawa Forest Experiment Station with 29 inches $(737 \mathrm{~mm}$ ) of precipitation per year, the growth of the hybrid is impressive, and further trials are warranted. With proper porcupine control the Dunkeld larch hybrid or other European $x$ Japanese hybrids should be tested further on deep, well aerated soils in the Great Lakes-St. Lawrence Forest Region (Rowe 1972).

To capitalize on the vigour and uniformity of the $F_{1}$ hybrid, seed from seed orchards producing $F_{1}$

TABLE 1. Height and diameter of 43-year-old Japanese larch and Dunkeld hybrid larch grown at the Petawawa Forest Experiment Station

Species

Japanese larch

Dunkeld hybrid larch

a $\mathrm{t}=-4.82(\mathrm{P}<01)$ d.f. $=13$

b $\mathrm{t}=-2.39(\mathrm{P}<.05)$ d.f. $=13$ 
hybrid seed should be preferred over stands producing $F_{2}$ or $F_{3}$ hybrid seed (which produce much more variable plant material). Furthermore, seed for future trials in eastern Canada should originate from seed orchards of selected provenances of the parental species. Seed is available in Europe from seed orchards of Alps $x$ Japanese, Polish $x$ Japanese and Sudeten $x$ Japanese hybrid larch. The plus trees that went into these seed orchards were selected in the western maritime climate of northwestern Europe and may not be the type best adapted for the continental part of eastern Canada. The seed from European seed orchards can be used with caution until we have plus trees of both parental species which are selected in eastern Canada and therefore better adapted to our soils and climates.

\section{References}

COOK, DAVE. 1969. Planted larch in New York. D. Cook, Albany, N.Y. 117 p.

ELIASON, E. J. and D. E. CARLSON. 1963. Comparative volume production of some species of larch. New York Cons. Dep., Notes on Forest Investigation No. 46. 2 p.

HENRY, A. and M. G. FLOOD. 1919. The history of the Dunkeld larch, Larix eurolepis, with notes on other hybrids. Proc. Royal Irish Acad. 35: 55-56.

ROWE, J. S. 1972. Forest regions of Canada. Can. Forest Serv. Pub. 1300. $172 \mathrm{p}$.

\section{White spruce limestone ecotypes}

\author{
A. H. TEICH and M. J. HOLST \\ Petawawa Forest Experiment Station \\ Canadian Forestry Service \\ Chalk River, Ontario
}

White spruce (Picea glauca (Moench) Voss) limestone ecotypes have been demonstrated in the laboratory (Farrar and Nicholson 1967) but not in the field. If provenances are indeed adapted to limestone soils, potential growth is now being lost by ignoring this fact in choosing provenances for reforestation. We present here experimental evidence supporting the hypothesis that limestone ecotypes do exist.

\section{Materials and methods}

Twelve provenances were collected from the southern part of the species' range in southern Ontario: six at random from soils of limestone parent material, and six at random from soils with granitic parent material. Soil types were classified by reference to maps such as Ontario Ministry of Natural Resources Landtype Patterns, and by visual examination. Soils at the root zones were acidic or basic according to the soil parent material.

All provenances were planted in two experimental sites within 35 miles $(56 \mathrm{~km})$ of each other, in Ontario. One site had a highly calcareous soil (Lake Dore $77^{\circ} 5^{\prime} \mathrm{W}$ Long, $45^{\circ} 37^{\prime} \mathrm{N}$ Lat.) and the other (Chalk River, $77^{\circ} 32^{\prime}$ W Long., $45^{\circ} 57^{\prime}$ $\mathrm{N}$ Lat.) had a granitic soil. In the B horizons the soil $\mathrm{pH}$ 's were 6.6 and 4.7 respectively and the calcium concentrations 12.5 and $1.7 \mathrm{meg} / 100 \mathrm{~g}$. Detailed soil descriptions of the experimental sites have
White spruce provenances from soils with limestone parent material, and non-limestone parent material were planted on calcareous and non-calcareous soils. The limestone provenances grew the most on calcareous soils: the non-limestone provenances grew the most on non-calcareous soils. Limestone ecotypes have evolved by natural selection.

been published (Burger 1966, and the Golden Lake Map S8 71, Ont. Min. Nat. Res., Division of Forests, Res. Br.). Climate at the two experimental sites is similar.

At each site the experimental plantations were in 10 tree plots with 5 randomized blocks at Lake Dore, and 12 randomized blocks at Chalk River. Seedlings of 2-2 stock were planted. Detailed provenance descriptions have been published (Teich 1973) and experimental design descriptions are on file at the Petawawa Forest Experiment Station (files $194 \mathrm{D}-2,194 \mathrm{M}-1$ ). Survival and height were measured when the trees were 15 years old from seed.

\section{Results and discussion}

Differences in survival among provenances were small and not significant statistically. Average survival was $80 \%$ at the limestone site and $90 \%$ at the granitic site.

Growth in general was better at the granitic site (Table 1) but this can not be attributed to soil parent material because other, minor differences, such as soil texture and micro-climate may have influenced growth.

Provenances differed in growth. At the limestone site the limestone provenances were $10 \%$ taller than the granitic provenances. At the granitic site the granitic provenances were $9 \%$ taller than the 